\title{
STRUCTURAL AND TRANSPORT PROPERTIES OF HYBRID ORGANIC INORGANIC SILICA MEMBRANES
}

\author{
Haryadi $^{*}$
}

\begin{abstract}
The series of hybrid organic-inorganic silica materials have been prepared by introducing organic ligands materials based on sol-gel processing of alkoxysilanes for potential applications in membrane design for pervaporation. The materials were characterized using structural and dynamic techniques to gain information about the formation of micro- and mesoporous silicates. The dynamic interaction within silica matrices were investigated using FTIR, Raman Spectroscopy, Solid State NMR Spectroscopy, Physisorption and SEM. The transport properties of the hybrid materials were observed by monitoring the diffusion behavior of water and several selected solvents using Pulsed Field Gradient NMR. The self-diffusion of water and organic solvents in the hybrid silica materials were two to three orders of magnitude smaller than in the liquid bulk suggesting restricted diffusion at the pore surface. The effect of surface polarity also contributed to water and solvents diffusivities. The temperature dependence of diffusion was useful to derive the activation energy whereas the dependence on NMR observation time provided information on both tortuosity and pore connectivity of the hybrid silica materials. These materials have potential uses in gas and liquid separation such as pervaporation.
\end{abstract}

Keywords: silica membrane, physisorption, sol-gel, self-diffusion, solid state NMR.

\begin{abstract}
ABSTRAK
Suatu seri material hibrid silika organik-anorganik dibuat dengan cara menempatkan berbagai ligan melalui proses sol - gel senyawa alkoksilan untuk diaplikasikan sebagai membran pada proses pervaporasi. Material hibrid silika yang dibuat, dikarakterisasi dengan beberapa teknik pengukuran struktur dan dinamik untuk mendapatkan informasi tentang pembentukan silikat micro dan mesopori. Interaksi dinamika didalam material silika diamati dengan menggunakan spektrofotometer inframerah, Raman, Resonansi Magnit Inti (NMR)-Solid State, Physisorption dan SEM. Sifat perpindahan massa didalam material silka ini diamati dengan memonitor laju difusi air dan beberapa pelarut menggunakan Pulsed Field gradient-NMR. Laju difusi air dan beberapa pelarut didalam material silika ini menunjukkan penurunan 100 hingga 1000 kali lebih kecil dibandingkan laju difusi didalam larutan. Hal ini memberikan indikasi terjadinya difusi-terbatas (restricted diffusion) pada permukaan pori-pori membran. Karakteristik polaritas dari bahan juga berpengaruh terhadap difusitas air dan pelarut-pelarut tersebut. Informasi untuk parameter energi aktifasi diperoleh melalui pengamatan pengaruh temperatur terhadap laju difusi, sedangkan pengaruh waktu pengamatan (observation time) memberikan informasi tentang hambatan (tortuosity) pelarut berdifusi serta koneksi antar pori (pore connectivity) didalam material hibrid silika ini. Material hibrid ini memiliki potensi besar untuk digunakan sebagai membran dalam proses pemisahan gas serta pervaporasi.
\end{abstract}

Kata kunci: hibrid silika, sol-gel, NMR, difusi.

\section{INTRODUCTION}

Organically functionalized hybrid sol gel materials, obtained from the hydrolysis and cocondensation of TMOS or TEOS with other organosiloxanes $\left(\mathrm{R}_{\mathrm{x}} \mathrm{Si}(\mathrm{OR})_{4 \mathrm{x}}\right.$, where $\mathrm{R}$ is alkyl groups), has attracted increasing attention in recent years because of their potential applications in such fields as hard coating for optics, catalysis, selective membranes or molecular recognition (Raman et al. 1996; Raman and Brinker 1995; Brinker and Scherer 1990). The major driving forces behind the intensive activities in these organic inorganic hybrid materials are the new and different properties of nanocomposites which have domain sizes typically in the range 1-100 nm, being the average size of the components or phase. In these materials, TEOS precursors function as building blocks to construct the framework while the organosiloxanes with non hydrolysable organic groups contribute both framework silica units and the organic surface functional groups. Various molecular structures are formed depending on the functionality of the organosiloxane and its proportion in the mixture.

The inorganic components can provide excellent mechanical and optical properties such as surface hardness, thermal and structural stability, transparency, and high refractive index. Introduction of organic moieties within the organic silicate framework may increase the flexibility of mesoporous films and fibres and reduce the brittleness of films or monoliths and are also helpful in the design of the surface polarity of the materials (Brinker and Scherer 1990; Pang et al. 2001).

In this paper, the structural properties of hybrid silica materials prepared from a low temperature sol gel process are discussed. Several techniques are used to characterise the materials

\footnotetext{
Department of Chemical Engineering, Bandung State of Polytechnic

E-mail: rifqishabira@gmail.com; harifso@yahoo.com
} 
namely, ${ }^{29} \mathrm{Si}$ Solid State NMR, Infrared and Raman spectroscopy, gas physisorption, SEM and pulsed field gradient spin echo (PFGSTE) NMR. The main goal of the experiments is to characterize and if possible to predict the transport phenomena in the hybrid silica materials. This will enable design of new membrane material for gas separation and pervaporation applications.

\section{METHODS AND MATERIALS}

The procedure for the preparation of the hybrid silica materials was adopted from that in the literature with some modification (Pang et al. 2001). In general TEOS (tetraethoxysilane) and MTES (methyltriethoxysilane) were prehydrolysed with deionized water in ethanol using $\mathrm{HCl}$ as catalyst at [MTES]:[TEOS]:[ $\left.\mathrm{H}_{2} \mathrm{O}\right]:[\mathrm{EtOH}]:[\mathrm{HCl}]$ molar ratio of $x: 1-x: 4: 3: 0.001$ where $x$ ranged from 10 to $50 \mathrm{~mol} \%$, at about $70{ }^{\circ} \mathrm{C}$ for $2-3 \mathrm{~h}$. All samples in the petri dish were then cooled to room temperature and sealed with cellophane films containing several pinholes to allow for slow evaporation of solvent and reaction byproducts at room temperature

IR spectra were recorded using a FTIR Nicolet AVATAR 320. Raman spectra were performed using a Renishaw 2000 Raman microscope with a $633 \mathrm{~nm} \mathrm{He}-\mathrm{Ne}$ laser. ${ }^{29} \mathrm{Si}$ cross polarization (CP) magic angle spinning (MAS) NMR spectra were measured on an Inova 300 Chemagnetics (Varian) instrument using a $7.5 \mathrm{~mm}$ zirconia rotor sample holder and rotation frequency of $2 \mathrm{KHz}$. Pulse width $4-6$ $\mu \mathrm{s}$, variable contact time from 0.005 to $20 \mathrm{~ms}$, recycle delay $5 \mathrm{~s}$ and ${ }^{1} \mathrm{H}$ RF field of $62 \mathrm{KHz}$ were selected. For the ${ }^{29} \mathrm{Si}$ single pulse experiment (SPE), pulse width $(1.2-1.6 \mu \mathrm{s}), \mathrm{RF}$ decoupling power of $62 \mathrm{KHz}$ and relaxation delay $(80-120$ s) were chosen to take into account the long $T_{1}$ relaxation times. Chemical shifts of silicon were referenced to kaolin which appears at $-91.5 \mathrm{ppm}$. PFGSTE NMR experiments were measured on an AMX 500 spectrometer (Bruker) using $5 \mathrm{~mm}$ NMR tubes. The specific surface area and porosity were measured using the BET method on a Micromeritics ASAP 2000 Gas Sorption Analyzer. The sample was placed in a glass tube and immersed in a bath of liquid nitrogen to control the temperature at $77 \mathrm{~K}$. Outgassing was carried out at $120{ }^{\circ} \mathrm{C}$ in a vacuum $(10 \mu \mathrm{m} \mathrm{Hg})$ to drive off any adsorbed water in the sample prior to testing.
Chemically resistant Anodisc 25 aluminium oxide filters were used as ceramic supports. These membranes are flat and circular $(21 \mathrm{~mm}$ diameter) having polypropylene support rings. They are $60 \mu \mathrm{m}$ thick and have about $50 \%$ surface porosity and $0.2 \mu \mathrm{m}$ pore size. Colloidal silica (LUDOX HS-40, $40 \mathrm{wt} \% \mathrm{SiO}_{2}$ in water, $\mathrm{pH}=9$ ) was acidified to $\mathrm{pH} 4$ by adding $\mathrm{HNO}_{3}$ $50 \mathrm{v} / \mathrm{v} \%$. In the preparation of silica membranes, this colloidal silica was used to reduce the pore size of the substrate.

Silica membranes were formed by a spin coating deposition method. The silica sols (procedure 2.1.2.2) were deposited onto the treated substrate by using CHEMAT TECHNOLOGY, KW-4 spin coater. Typically, $0.5 \mathrm{ml}$ of the silica sols was deposited on the treated Anodisc filter by spin coating at spinning rate of $2000-2500 \mathrm{rpm}$ for $10-20 \mathrm{~s}$. Another coating of silica sol on the same surface was added, using the same volume and spinning rate.

\section{RESULTS AND DISCUSSION}

\subsection{Vibrational spectroscopies}

Infrared and Raman spectroscopies enabled functional groups to be detected within the silica matrices. The peak at $1250 \mathrm{~cm}^{-1}$ indicates that the $\mathrm{Si}-\mathrm{C}$ bond has been introduced and did not cleave in forming the silica hybrid matrices. The symmetric C-H stretching vibrations for the methyl groups appear at about 2925 and 2975 $\mathrm{cm}-1$ The silanol and silicon oxide bands exist at the surface of the silica as indicated at $960 \mathrm{~cm}^{-1}$ and $1080 \mathrm{~cm}^{-1}$ respectively.

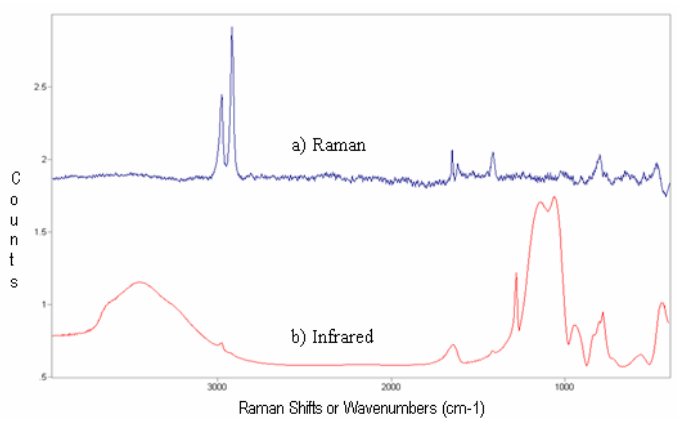

Figure 1. Raman (a) and Infrared (b) spectrum of TEOS/MTES (TE5-MT5) gel.

\section{$3.2{ }^{29} \mathrm{Si}$ CPMAS NMR}

The magic angle spinning (MAS) technique makes it possible to obtain well resolved ${ }^{29} \mathrm{Si}$ NMR spectra for silica-based sol gel materials. In addition, the intensities of the ${ }^{29} \mathrm{Si}$ peaks can be significantly enhanced by using the ${ }^{1} \mathrm{H}-{ }^{29} \mathrm{Si}$ crosspolarization technique (CP) when ${ }^{1} \mathrm{H}$ nuclei exhibit a good polarization transfer to ${ }^{29} \mathrm{Si}$. The efficiency of the polarization transfer between 
the protons and the ${ }^{29} \mathrm{Si}$ nuclei depends strongly on the ${ }^{1} \mathrm{H}-{ }^{29} \mathrm{Si}$ dipolar coupling and thus on the distance between protons and ${ }^{29} \mathrm{Si}$ nuclei as well as on the mobility of the corresponding groups.

In ${ }^{29} \mathrm{Si} \mathrm{CP}$ (Cross Polarisation) MAS NMR spectra, the signals due to various substituents on silicon can be assigned and the average structure of the functionalized gel characterized as represented in Figure 2. It can be seen that the hybrid silica materials contains five different silicon environments namely, $\mathrm{CH}_{3}-\mathrm{SiO}_{2}(\mathrm{OH})$ $\left(\mathrm{T}_{2}\right), \mathrm{CH}_{3}-\mathrm{SiO}_{3}\left(\mathrm{~T}_{3}\right), \mathrm{SiO}_{2}(\mathrm{OH})_{2}\left(\mathrm{Q}_{2}\right), \mathrm{SiO}_{3}(\mathrm{OH})$ $\left(\mathrm{Q}_{3}\right)$ and $\mathrm{SiO}_{4}\left(\mathrm{Q}_{4}\right)$.

Cross-polarization dynamics is usually described within the framework of spin thermodynamics considering two reservoirs corresponding to the abundant $I$-spin $\left({ }^{1} \mathrm{H}\right)$ and the rare $S$-spin $\left.{ }^{29} \mathrm{Si}\right)$. This model predicts an exponential build-up of $S$-spin magnetization in the rotating frame, characterized by $1 / \mathrm{T}_{\text {Is. }}$. If the loss of spin-locked proton magnetization in the rotating frame is taken into account by the relaxation rate $1 / T_{1 e}$, the time dependence of the $S$-spin magnetization is [20]:

$$
M(t)=\frac{M_{0}\left\{\exp \left\{-t / T_{S i H}\right]-\exp \left[-t / T_{1 p}\left({ }^{1} H\right)\right]\right\}}{\left.\mid T_{S H H} / T_{1 p}\left({ }^{1} H\right)\right)}
$$

The polarization dynamics of $\mathrm{Q}_{4}$ units can give information on the proximity of $\mathrm{T}$ units in TEOS/MTES in hybrid derived samples. The corresponding parameters are summarized in Table 1, together with parameters corresponding to TEOS and TEOS/MTES. $\mathrm{T}_{\mathrm{Si}-\mathrm{H}}$ is related to the dipolar coupling and thus to the ${ }^{1} \mathrm{H}-{ }^{29} \mathrm{Si}$ distance. For $\mathrm{Q}_{4}$ units, the influence of mobility can be neglected as a first approximation.

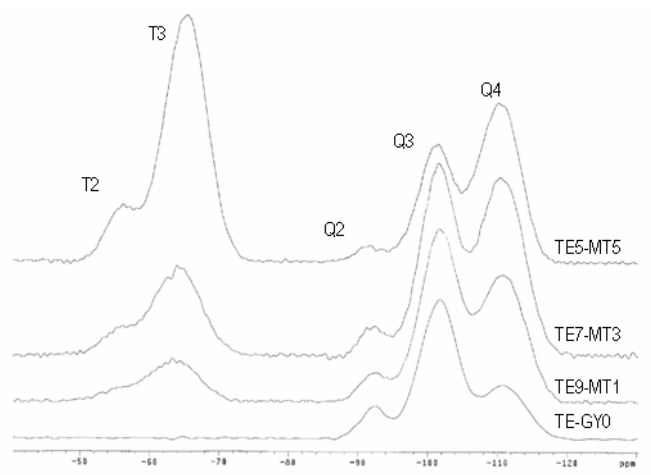

Figure 2. ${ }^{29} \mathrm{Si}$ CPMAS NMR of hybrid silica

materials with different amounts of MTES

(TE9MTE1 $10 \mathrm{~mol} \%$, TE8MTE2 $20 \mathrm{~mol} \%$ and TE5MTE5 $50 \mathrm{~mol} \%$ ).

In TEOS derived silica gel, the $\mathrm{T}_{\mathrm{Si}-\mathrm{H}}$ value is long due to poor protonated environments as also observed by (Zumbulayadis 1991). In the gels containing $\mathrm{T}$ units, the $\mathrm{T}_{\mathrm{Si}-\mathrm{H}}$ values are reduced indicating an increased number of protons in the environment of $\mathrm{Q}_{4}$ units. The close proximity between $\mathrm{Q}_{4}$ units and $\mathrm{T}$ units is also supported by (Fyfe et al. 1992) who observed TEOS/MTES derived gels by two dimensional ${ }^{1} \mathrm{H} /{ }^{29} \mathrm{Si}$ correlation experiments which clearly demonstrated that the two components are not phase separated.

Table 1. ${ }^{29} \mathrm{Si}$ CP/MAS NMR experiments; Parameters for peak due to $\mathrm{Q}_{4}$.

\begin{tabular}{|c|c|c|c|}
\hline Sample & $\begin{array}{c}\text { Methyl content } \\
(\mathrm{mol} \%)\end{array}$ & $\begin{array}{c}\mathrm{T}_{\text {Si-H }} \\
(\mathrm{ms})\end{array}$ & $\begin{array}{c}\mathrm{T}_{1 \varrho}\left({ }^{1} \mathrm{H}\right) \\
(\mathrm{ms})\end{array}$ \\
\hline TEG0 & - & 24.4 & $($ long $)$ \\
\hline MTE2 & 20 & 8.6 & 42.5 \\
\hline MTE5 & 50 & 5.1 & 13.3 \\
\hline
\end{tabular}

TE $=$ TEOS; MTE $=$ MTES

The organic functional groups can be controlled in order to produce more hydrophobic character on the surface of the materials. CP MAS NMR can not be used to obtain quantitative data on the different Si sites due to the large distance between protons and some of the $\mathrm{Q}_{4} \mathrm{Si}$ atoms (Peeters et al. 1995). Therefore for quantitative data single pulse excitation (SPE) MAS NMR with a longer recycle delay $\left(>3 \times \mathrm{T}_{1}\right)$ are performed and the areas corresponding to each of the Si sites are obtained from deconvolution of the ${ }^{29} \mathrm{Si}$ MAS NMR spectra.

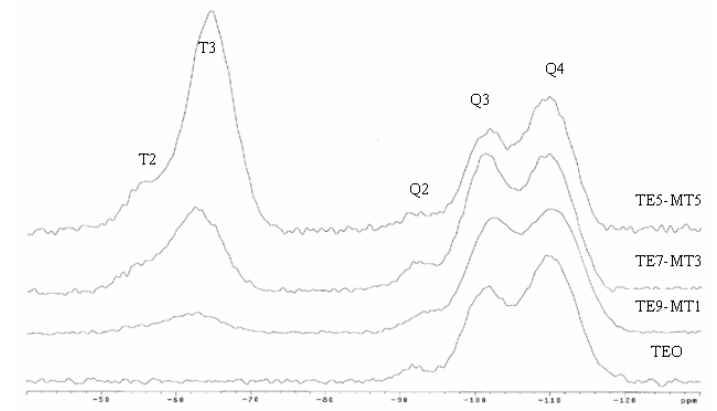

Figure 3. ${ }^{29}$ Si MAS NMR spectra of

TEOS/MTES gels with various MTES contents.

Figure 4 shows the methyl content of the silica materials as prepared (sol) and after gelation (gel) calculated from ${ }^{29} \mathrm{Si}$ SPE MAS NMR measurement. A linear relationship is observed between methyl content in the sol and the gel suggesting the degree of condensation approaches $100 \%$ based on the sample preparation. 


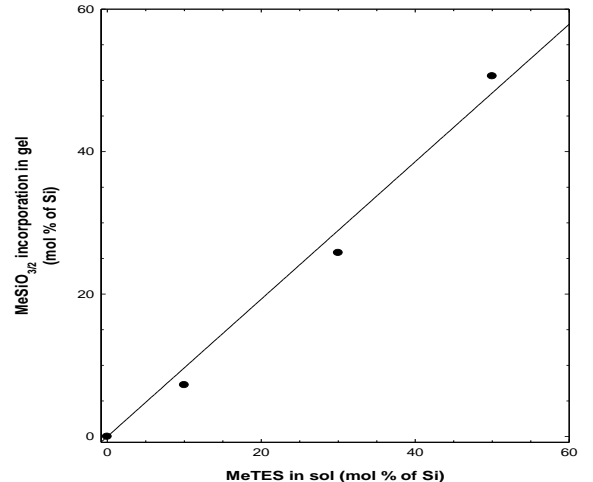

Figure 4. Comparison of the methyl content $\left(\mathrm{T}^{3}\right.$ $\left.\left(\mathrm{CH}_{3}-\mathrm{SiO}_{3}\right)\right)$ in the sols and the methyl content in the gel calculated from 29Si SPEMAS NMR measurements.

\subsection{Physisorption}

Permeability and selectivity are two important factors which govern the applications of the hybrid materials in separation processes. The permeability is controlled by the pore volume fraction whereas the selectivity is determined by the pore size and its distribution. Figure 4 displays nitrogen sorption measurements of various hybrid silica materials. A reversible type I isotherm that is typical of a microporous structure is obtained. Table 2 also provides data derived from physisorption measurements of hybrid silica materials. the mechanism of the selectivity, the interactions between solvent, solute and the silica materials on the microscopic level should be obtained (Fyfe et al. 1992). The diffusional motion of a small molecule e.g. water in inhomogeneous materials such as porous materials depends on the structure of the materials and the diffusion time. The motion called restricted diffusion, shows individual time dependence related to each structure.

The pulsed-field-gradient NMR or spaceresolved NMR such as PFGSTE (Pulsed Field Gradient Stimulated Echo) NMR is a non invasive technique for studying transport phenomena at the microscopic scale. By applying a magnetic field-gradient, the NMR frequency of a hydrogen nucleus is determined by the position of the hydrogen containing molecule in the magnetic field. On this basis, the displacement of water molecules is detectable and the selfdiffusion coefficient $D, \mathrm{~m}^{2} \mathrm{~s}^{-1}$, can be measured. Furthermore the method can be used to measure the diffusion coefficient of molecules in the porous materials at various diffusion times and to study the relationships between diffusion coefficient and porous material structure [8]. Self-diffusion coefficients are calculated by measuring the decrease the NMR signal intensity with increasing magnetic field gradients

Table 2. Pore structural parameters and surface areas of pure silica and hybrid silica gels.

\begin{tabular}{|c|c|c|c|c|c|c|}
\hline Sample Code & $\begin{array}{c}\text { S BET } \\
\mathrm{m}^{2} \mathrm{~g}^{-1}\end{array}$ & $\begin{array}{c}\mathrm{PV} \\
\mathrm{cm}^{3} \mathrm{~g}^{-1}\end{array}$ & $\begin{array}{c}\mathrm{PD} \\
\mathrm{nm}\end{array}$ & $\begin{array}{c}\text { MP-V } \\
\mathrm{cm}^{3} \mathrm{~g}^{-1}\end{array}$ & $\begin{array}{c}\text { MP-A } \\
\mathrm{m}^{2} \mathrm{~g}^{-1}\end{array}$ & $\begin{array}{c}\text { Porosity } \\
\%\end{array}$ \\
\hline TE-GY0 & $456 \pm 14$ & 0.22 & 1.4 & 0.18 & 387 & 32 \\
\hline TE9-MT1 & $389 \pm 1$ & 0.19 & 1.5 & 0.13 & 285 & 29 \\
\hline TE8-MT2 & $422 \pm 3$ & 0.21 & 1.5 & 0.14 & 290 & 31 \\
\hline TE7-MT3 & $556 \pm 3$ & 0.28 & 1.5 & 0.14 & 293 & 37 \\
\hline TE5-MT5 & $440 \pm 8$ & 0.24 & 1.6 & 0.09 & 210 & 34 \\
\hline
\end{tabular}

$\mathrm{S}_{\mathrm{BET}}=\mathrm{BET}$ surface area; $\mathrm{PV}=$ Pore Volume; $\mathrm{PD}=$ Average Pore Diameter;

$\mathrm{M}-\mathrm{PV}=$ Micropore Volume; $\mathrm{MP}-\mathrm{A}=$ Micropore Area

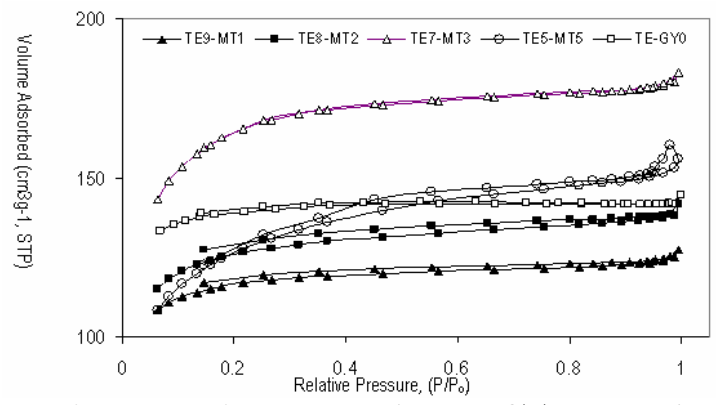

Figure 5 Nitrogen Isotherm of TEOS and TEOS/MTES gels.

\subsection{Water Diffusion measured by PFG NMR}

The selectivity strongly depends on the relative solubility and diffusivity of solvent and solute in the materials. In order to understand
(Callaghan 1993; Stejskel and Tanner 1965; Stallmach and Karger 1999).

The self-diffusion coefficient of bulk water (Do) is $2.29 \times 10^{-9} \mathrm{~m}^{2} \mathrm{~s}^{-1}$ which is the same as Holz's results of $2.29 \times 10^{-9} \mathrm{~m}^{2} \mathrm{~s}^{-1}$ for PFGSE NMR calibration purposes (Cussler 1997). This therefore confirms the reliability of the PFG NMR experiments.

An Arhenius plot of the diffusion data observed at temperature from 288 to $328 \mathrm{~K}$ provides the activation energy, Ea, from $D=A \exp \{-E a / R T\}$ where $\mathrm{A}$ is a constant, $\mathrm{R}$ the gas constant, and $\mathrm{T}$ the absolute temperature. Figure 5 displays the Arhenius plot for D of water in hybrid silica 
materials. While these are not perfectly linear, they can be used to estimate activation energy Stallmach and Karger 1999) for water diffusion as shown in Table 3. diameters of about $0.2 \mu \mathrm{m}$ and is $60 \mu \mathrm{m}$ thick. Another membrane support made from polycarbonate, denoted Isopore, with pore diameters $0.5 \mu \mathrm{m}$ was also considered.

Table 3. Water self diffusion in hybrid silica materials, $\delta=2 \mathrm{~ms}$ at $298 \mathrm{~K}$.

\begin{tabular}{|c|c|c|c|c|c|}
\hline Water in & $\begin{array}{c}\mathrm{CH}_{3}(\mathrm{~mol} \\
\%)\end{array}$ & $\begin{array}{c}\mathrm{D} / 10^{-10} \\
\left(\mathrm{~m}^{2} \mathrm{~s}^{-1}\right)\end{array}$ & $\begin{array}{c}\text { Activation Energy, Ea, } \\
\mathrm{kJ} \mathrm{mol}^{-1}\end{array}$ & $\begin{array}{c}\mathrm{PD} \\
(\mathrm{nm})\end{array}$ & Porosity \\
\hline bulk & - & 22.9 & 22.3 & - & - \\
\hline TE-GY0 & 0 & 0.6 & 22.9 & 1.4 & 0.32 \\
\hline TE8-MT2 & 20 & 1.5 & 24.5 & 1.5 & 0.31 \\
\hline TE5-MT5 & 50 & 0.8 & 24.4 & 1.6 & 0.34 \\
\hline
\end{tabular}

Diffusion coefficients decreased as diffusion time increased which suggests the possibility of the restricted diffusion of water molecules in the pores. The result indicates that the effective restricted diffusion coefficients of water in the hybrid silica materials at $298 \pm 0.5 \mathrm{~K}$ are three orders of magnitude smaller than in the neat liquid measured by PFGSTE NMR as shown in Table 3. These rather small diffusion coefficients, relative to bulk water could be attributed to the strong interaction of water molecules with the pore surface and the relatively small effective pore size

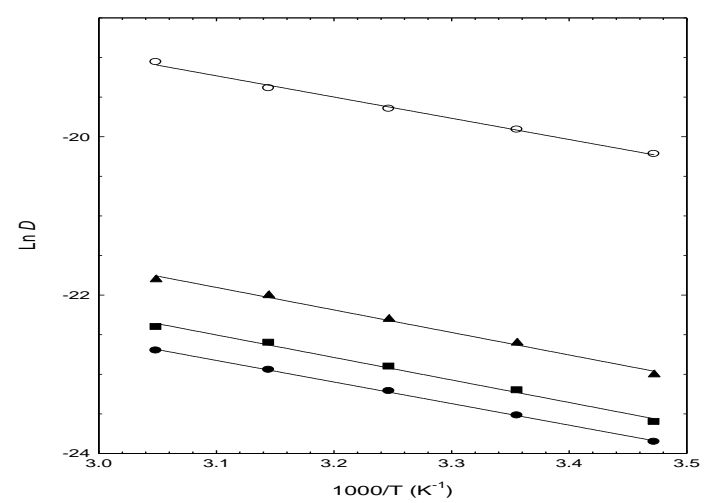

Figure 6. Arrhenius plot of water in hybrid silica materials

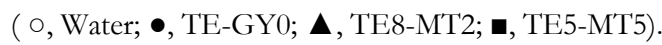

\subsection{Morphology of hybrid silica membranes}

Figure $7 \mathrm{a}$ and $7 \mathrm{~b}$ show the anodisc-alumina support material which has surface pore
To achieve ideal membranes for gas separation or pervaporation, pore size modification is required. This follows the established method developed by Moadeb and Koros (1995) through occlusion of the surface pores of the aluminium oxide with colloidal silica (Ludox 40), prior to deposition of the active layer consisting of microporous silica or hybrid silica. Figure $7 \mathrm{c}$ shows the anodisc after three deposition steps of the colloidal silica sols indicating that parts of the large pores were covered on the surface of the Anodisc membrane though some pinholes/smaller pores still existed with pore sizes of about $50-100 \mathrm{~nm}$. The pinholes might be caused by the nonuniformity of the occlusion process. Since a very small area of the membrane is viewed by the electron microscope, it is premature to conclude that the surface after three deposition steps is thoroughly covered and free of defects.

Figure 8 displays the results of spin coating at $2000 \mathrm{rpm}$ for the polymeric sols of TEOSMTES hybrid silica membranes (TE8-MT2 and TE5-MT5). No cracks were observed for these hybrid membranes whereas it is difficult to obtain non-cracked films for pure silica, TEOS, sols by spin coating. Therefore the preparation was only focused on the hybrid silica membranes. Furthermore, it also can be seen that there are still some fine gaps on the surface of the hybrid silica film although the spin coating step was repeated 10 times. These might be due

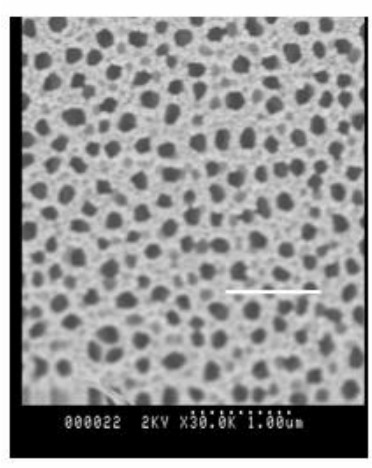

a) Top view (Bar: $1 \mu \mathrm{m})$

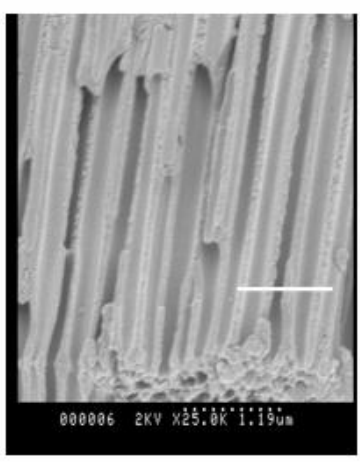

b) Cross section (Bar: $1.2 \mu \mathrm{m}$ )

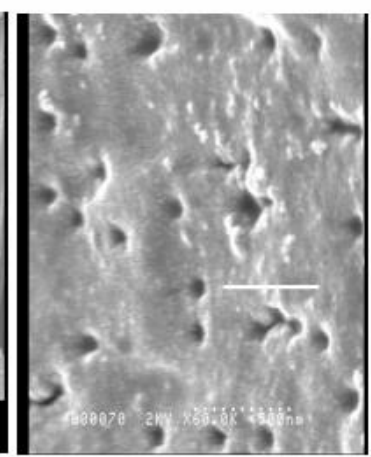

c) deposit of silica particles (Bar: $500 \mathrm{~nm}$ )

Figure 7. SEM images of Anodisc membrane before and after deposition of silica particles. 
to the nonuniformity or incomplete intermediate layer formation of silica particles during plugging up of the pores. The viscosity of the sol and the water to silica ratio might also contribute to the inhomogeneous structure of the film during spin coating and drying of the silica films.

The spin coating was not prolonged since the thickness of the active layer (polymeric silica) had already exceeded $1 \mu \mathrm{m}$, Figure 9a, which is

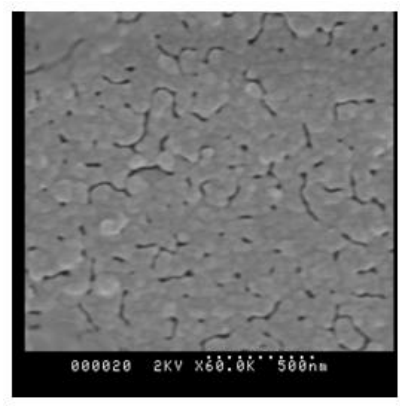

a) TE8-MT2 it can be seen that by increasing the methyl content in the hybrid silica materials, the water contact angle, $\theta$, rises from $(30 \pm 2)^{\circ}$ for TEOS $\left(\right.$ TE-GY0) to $(110 \pm 4)^{\circ}$ and $(130 \pm 3)^{\circ}$ for TE8-MT2 and TE5-MT5 respectively, Figure 10.

The hydrophobicity of the silica membranes increases systematically as the methyl content increases although the trend is not linear.

The results of water contact angle

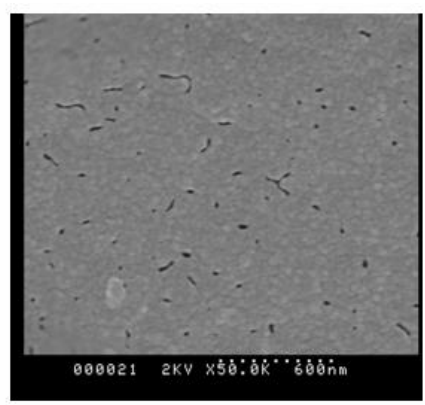

b) TE5-MT5

Figure 8. SEM images (top view) of the silica membranes after spin coating at $2000 \mathrm{rpm}$ at $298 \mathrm{~K}$.

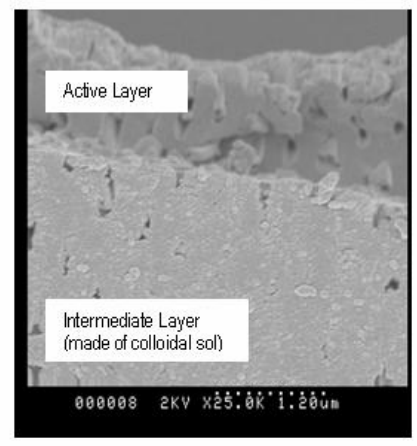

a)

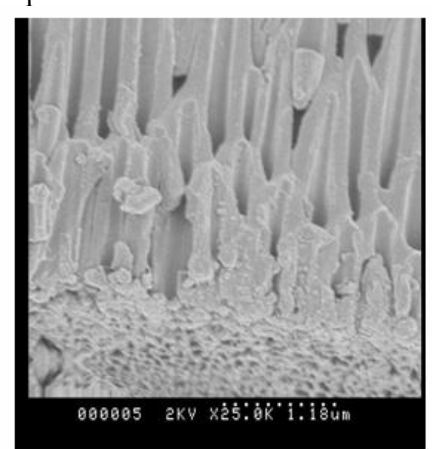

b)

Figure 9. SEM images of cross sections of active layer and intermediate layer

a) and b) cross section of alumina support and bottom view after spin coating for TE8-MT2 membrane.

beyond the recommended active layer thickness (i.e. $100 \mathrm{~nm}$ ) for either gas separation or pervaporation applications. Furthermore, Figure $9 \mathrm{~b}$ displays the bottom view of the alumina support showing no blocking of pores after the colloidal sol deposits and the spin coating process suggesting that the alumina support is not blocked by either silica polymer or silica particles and therefore the membranes can be trialled for pervaporation.

\subsection{Contact Angle}

Figure 10 shows the water contact angle $(\theta)$ measurements at $298 \mathrm{~K}$ after spin coating of the hybrid silica membranes on the intermediate layer. The alumina support before coating and after deposition of the intermediate layer gives close to zero water contact angle due to hydrophilic character. After five to six times repetition of water contact angle measurements, measurements are consistent with other observations of the hybrid silica xerogels. The TEOS (TE-GY0) sample contains a high proportion of silanol (Si-OH, $\mathrm{Q}^{3}$ unit) groups which makes it more hydrophilic as compared with hybrid silica materials whose surfaces not only consist of silanol groups but also methyl groups attached to $\mathrm{Si}$ ( $\mathrm{T}^{3}$ unit) as quantified by ${ }^{29} \mathrm{Si}$ SPE MAS NMR. The proportion of the silanol groups decreases as the methyl content increases leading to more hydrophobic character on the surface of the hybrid silica gels.

\section{CONCLUSIONS}

The characteristic of non-reactive organic groups in the pore surface of hybrid silica materials are observed from ${ }^{29} \mathrm{Si} \mathrm{CP} / \mathrm{MAS}$ NMR of variable contact time experiments. Hybrid silica gel compositions can be quantified by ${ }^{29} \mathrm{Si}$ SPE NMR. The total degree of condensation 
(DCT) increased as the amount of MTES increased. By comparing integrated intensities of the peaks with the Qn peaks in the ${ }^{29} \mathrm{Si} \mathrm{SPE}$ MAS NMR data, it was determined that the fraction of methyl modified silicon in the film was nearly identical to that of the precursors solution.

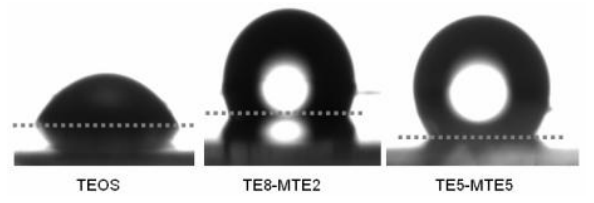

Figure 10. Shape of a water $\operatorname{drop}(\sim 3 \mu \mathrm{L})$ on the silica membranes with different Methyl contents. The dashed line indicates the film surface. The reflection of the drop is seen below the dashed line.

Introducing methyl groups into the silica network modified the silica surface properties to become hydrophobic; nevertheless microporosity could still be maintained. The BET surface area and porosity show significant variations but there are no clear trends with the amount of methyl groups whereas pore dimensions gradually increased as the methyl content increased.

The surface polarity of the hybrid silica samples affects water diffusivity and the effect is more pronounced when the carbon chain length or amount of alkyl substituents increases.

The activation energy of water in the hybrid silica materials, derived from temperature dependence, is somewhat higher as compared with the bulk liquid and is again influenced by the hydrophobicity as well as the pore sizes of the samples.

The feasibility of fabrication of thin hybrid silica membranes with different organosilicate content on inorganic substrates is demonstrated. The $0.2 \mu \mathrm{m}$ pores of the alumina support membranes were reduced by occlusion of colloidal silica particles although there small pores of about $50 \mathrm{~nm}$ diameter still exist. The spin coating of the polymeric sol of TEOS produced crack films whereas by introducing methyl groups during the sol-gel process, crack free films can be obtained.

The water contact angle increases as the methyl content increases from 0 to $50 \mathrm{~mol} \%$ in the hybrid silica membranes confirming the more hydrophobic character on the bulk surface of the membranes.

\section{REFERENCES}

Brenner, H. and Gaydos, L.J. (1977), 'J. Colloid Interface Sci.', 58, p. 312.
Brinker, C.J. and Scherer, G.W. (1990), Sol Gel Science, Academic Press, San Diego, CA.

Callaghan, P.T. (1993), Principles of Nuclear Magnetic Resonance Microscopy, Oxford University Press, Oxford.

Carniglia, S.C. (1986), J. Catal., 102, p. 401.

Cussler, E.L. (1997), Diffusion, Mass Transfer in Fluid Systems, Cambridge Uni. Press, Cambridge, UK.

Dire, S., Pagani, E., Babonneau, F., Ceccato, R. and Carturan, G. (1997), J. Mater. Chem., 7, p. 67.

Fyfe, C.A., Zhang, Y. and Aroca, P. (1992), J. Am. Chem. Soc., 114, p. 3252.

Holz, M, Weingartner, H. (1991), J. Magn. Res., 92, p. 115.

Karger, J. and Ruthven, D.M. (1992), Diffusion in Zeolite and Other Microporous Solids, John Wiley, New York.

Koenig, J.L. (1992), Spectroscopy of Polymers, Washington D.C.

Moaddeb, M. and Koros, W.J. (1995), Ind. Eng. Chem. Res., 34, pp. 263-274.

Latour, L.L., Kleinberg, R.L., Mitra, P.P. and Sotak, C.H. (1995), J. Magn. Res. Ser. A, 112, p. 83.

Pang, J.B., Qiu, K.Y. and Wei, Y. (2001), J. Non-Cryst. Solids, 283, p. 101.

Peeters, M.P.J, Wakelkamp, W.J.J. and Kentgens, A.P.M. (1995), J. Non-Cryst. Solids, 189, p. 613.

Perry, R.H. and Green, D.W. (1998), Perry's Chemical Engineers' Handbook, McGraw- Hill, New York.

Raman, N.K. and Brinker, C.J. (1995), J. Membrane. Sci., 105, p. 273.

Raman, N.K, Anderson, M.T. and Brinker, C.J. (1996), Chem. Mater., 8, p. 1682.

Seland, J.G., Ottaviani, M. and Hafskjold, B. (2001), J. Colloid Interface Sci., 239, p. 168.

Stallmach, F. and Karger, J. (1999), Adsorption, 5, p. 117.

Stejskal, E.O. and Tanner, J.E. (1965), J. Chem. Phys., 42, p. 288.

Suzuki, M. and Smith, J.M. (1972), Chem. Eng. J., 3, p. 256.

Vacassy, R.R.J.F, Hofmann, H., Choi, K.S. and Singh, R.K. (2000), J. Colloid Interface Sci., 227, p. 302.

Wakao, N. and Smith, J.M. (1962), Chem. Eng. Sci., 17, p. 825.

Zumbulayadis, N. and O'Reilly, J.M. (1991), Macromolecules, 24, p. 5294.

Diterima: 22 Januari 2007

Disetujui untuk diterbitkan: 14 Mei 2007 